\title{
BACTERIOLOGICAL STUDY IN CHRONIC SUPPURATIVE OTITIS MEDIA
}

\author{
A. V. S. Hanumantha Rao1, B. Vijay Kumar'2, Nasir Jani Shaik ${ }^{3}$ \\ ${ }^{1}$ Associate Professor, Department of ENT, Kakatiya Medical College, Warangal. \\ ${ }^{3}$ Assistant Professor, Department of ENT, Kakatiya Medical College, Warangal. \\ ${ }^{3}$ ENT Surgeon, Department of ENT, Warangal, Telangana.
}

\section{ABSTRACT}

\section{BACKGROUND}

Chronic Suppurative Otitis Media is the commonest inflammatory condition of the ear caused by bacteria and commonly seen in children of low socio-economic groups. Isolation of the causative bacteria and finding a suitable antibiotic by culture and sensitivity will control the infection of the middle ear.

\section{OBJECTIVE}

The aim of this study is to identify the bacteria responsible for infection in CSOM and to identify the appropriate antibiotic sensitivity.

\section{METHODS}

100 patients of CSOM were selected for this study, pus was collected from the infected ears by ear swab by suction with siegel speculum and sent to Microbiology Department for culture and sensitivity.

\section{RESULTS}

Aerobic organisms are isolated in majority of cases. Monomicrobial infection is more common than polymicrobial infection. Pseudomonas is the commonest aerobic organism grown in culture.

\section{CONCLUSION}

Careful and judicious use of antibiotics following culture and sensitivity test should be a standard practice, so as to limit the emergence of drug resistant bacteria and to provide dry ear.

\section{KEYWORDS}

CSOM, Bacteria (Aerobic and anaerobic), Culture and Sensitivity and Antibiotic.

HOW TO CITE THIS ARTICLE: Rao AVSH, Kumar BV, Shaik NJ, et al. Bacteriological study in chronic suppurative otitis media. J. Evolution Med. Dent. Sci. 2016;5(25):1324-1328, DOI: 10.14260/jemds/2016/311

\section{INTRODUCTION}

Chronic suppurative otitis media is one of the most common diseases of all age groups, especially in childhood. It is prevalent in developing countries and is a disease of low socioeconomic group. The most acceptable definition of CSOM is otorrhoea of at least 6 weeks' duration in the presence of tympanic membrane perforation. ${ }^{1}$ Chronic suppuration can occur with or without cholesteatoma. ${ }^{2}$

It is a chronic inflammation of the mucoperiosteal layer of the middle ear cleft, which leads to profuse ear discharge and hearing impairment that may have a serious long-term effect on language, auditory and cognitive development and on educational progress in children. ${ }^{3}$ Two clinicopathological types of CSOM exist: Tubotympanic; Atticoantral.

It tends to be persistent and destructive being able to lead to the production of irreversible sequelae. Its aetiopathogenesis is multifactorial and recurrent upper respiratory infections play an important role.

Financial or Other, Competing Interest: None.

Submission 10-02-2016, Peer Review 07-03-2016,

Acceptance 12-03-2016, Published 25-03-2016.

Corresponding Author:

A. V.S. Hanumantha Rao,

Associate Professor,

Department of ENT,

Kakatiya Medical College,

Warangal.

E-mail: suresh111161@gmail.com

DOI: $10.14260 /$ jemds $/ 2016 / 311$
Bacteria can reach the middle ear from nasopharynx through the Eustachian tube or from external auditory canal via a perforated tympanic membrane. The infectious process is characterized as polymicrobial, generally evolving with association of facultative bacteria, strict aerobic and anaerobic and the latter is present in $30-60 \%$ of the cases. ${ }^{4}$ Commonest organisms isolated from discharge are Pseudomonas aeruginosa, Staphylococcus aureus and Proteus species.5,3 These can be cultured by taking a swab from the discharging ear.5,4 and their in-vitro sensitivity to antibiotics is assessed.

Because of strategic location of the middle ear cleft, every inflammatory otitis media due to pathogenic microorganism carries potential complications.

After the introduction of antibiotics, the complications resulting from chronic otitis media significantly reduced. However, if we are to maximize the benefits available to us with such drugs, we need to choose between them with discrimination with an understanding of the microbial population and with their knowledge of their indications and limitations. ${ }^{6}$ This is especially true in chronic discharging ear where the offending organisms can be quite unpredictable, may be difficult to culture and may be resistant to all the available antimicrobials. ${ }^{7}$ The change of the bacterial population in chronic infection with time is a fact confirmed in the literature.

CSOM has received considerable attention, not only because of its high incidence and chronicity but also because of issues such as bacterial resistance and ototoxicity with 
topical and systemic antibiotics. The indiscriminate and haphazard use of antibiotics and poor followup of the patients has resulted in the emergence of multiple resistant strains of bacteria and the presence of low-grade infections. Since CSOM is a disease which can cause significant morbidity, a knowledge of prevailing flora and their susceptibility to antimicrobials will guide the clinician so as to prescribe the empirical regimen for more specific management can be provided to the patients.

Hence, this study is relevant in the present scenario. The purpose of this study was to isolate the aerobic and anaerobic organisms associated with CSOM and to describe the antibiogram of the aerobic isolates.

\section{OBJECTIVES OF THE STUDY}

1. To compare the incidence of aerobic and anaerobic bacteria in CSOM.

2. To identify the bacteria involved in safe and unsafe CSOM.

3. To know the antibiotic sensitivity pattern of aerobic bacteria.

\section{MATERIALS AND METHODS}

This study was done in the Department of ENT, MGM Hospital, Warangal. The bacteriological study was done in the Department of Microbiology, MGM Hospital, Warangal. A total of 100 patients were selected.

\section{Inclusion Criteria}

Patients were selected from Outpatient Department, who attended ENT Department, MGM Hospital, Warangal, with history of ear discharge for more than 3 months and actively discharging ear. All the patients selected for the study are above 5 years of age.

\section{Exclusion Criteria}

1. Those patients who received antibiotics 3 days prior in any form either systemic/topical have been excluded.

2. Children less than 5 years of age.

The patients thus selected were thoroughly examined after a detailed history. The clinical findings were recorded. Then the patients were explained about the procedure.

After taking informed consent, the external auditory canal was cleaned with Betadine, discharge from middle ear was obtained by suction with Siegel's pneumatic speculum. Two thin sterile cotton wool swabs were used to collect the pus for bacteriological study from the deeper part of the canal. One swab was inoculated in Cary-Blair transport medium for anaerobic culture and both the swabs were taken to the Department of Microbiology without any delay.

Conservative treatment included a systemic antihistamine, decongestant nasal drugs, broad-spectrum topical antibiotic ear drops. Patient is advised to come after 3 days to collect culture and sensitivity report. Depending on their culture and sensitivity report, a suitable antibiotic was started and prescribed for at least 1 week. Patient is asked to come back in case the discharge recurs.

In cases where there is a gross septic focus or anatomical abnormality, patient is advised surgery. Eg: Tonsillectomy in case of chronic tonsillitis; septoplasty in case of significant DNS; FESS in case of chronic sinusitis. In case if there is a large defect of tympanic membrane, patient is advised to go for reconstructive procedure (Myringoplasty/Tympanoplasty depending on the degree of hearing loss).

In the Department of Microbiology, one swab was used for inoculating into aerobic culture media, viz. blood agar, chocolate agar, nutrient agar and MacConkey's agar and were incubated at 370C for 24-48 hours. The swab sent in CaryBlair medium was subcultured onto blood agar and Thioglycollate medium and were incubated at $37^{\circ} \mathrm{C}$ for $48-72$ hours in McIntosh Filde's jar and Gaspak jar. In cases where the transport medium could not be used, the swab was inoculated directly into Robertson cooked meat medium from which it was subcultured onto blood agar and incubated anaerobically in McIntosh Filde's jar and Gaspak jar. The organisms were identified by culture characteristics, colony morphology, pigment production, beta haemolysis in blood agar, motility, Gram's staining and conventional biochemical tests.

All the organisms were subjected to antibiogram by Kirby-Bauer disc diffusion method according to the CLSI guidelines. Antibiotic discs used were ampicillin, amoxicillin, cotrimoxazole, ciprofloxacin, ofloxacin, cefpodoxime, ceftriaxone, ceftazidime and cefotaxime. Antibiogram was not done for anaerobic organisms because of lack of facilities.

\section{OBSERVATION}

\begin{tabular}{|c|c|c|}
\hline Duration & No. of Ears & Percentage \\
\hline$<5$ years & 70 & 58.82 \\
\hline 5-10 years & 39 & 32.78 \\
\hline$>10$ years & 10 & 8.40 \\
\hline Total & $\mathbf{1 1 9}$ & $\mathbf{1 0 0}$ \\
\hline \multicolumn{2}{|c|}{ Table 1: Duration of Ear Discharge } \\
\hline
\end{tabular}

Out of 119 ears the duration of discharge was less than 5 years in 70 ears, most of them were seeking periodical medical advice. The duration of ear discharge ranged between 5 to 10 years in 39 ears and it was greater than 10 years in 10 ears.

\begin{tabular}{|c|c|c|}
\hline Type of CSOM & No. of Ears & Percentage \\
\hline Tubotympanic & 93 & 78.15 \\
\hline Atticoantral & 26 & 21.85 \\
\hline Total & $\mathbf{1 1 9}$ & $\mathbf{1 0 0}$ \\
\hline \multicolumn{3}{|c|}{ Table 2: Type of CSOM } \\
\hline
\end{tabular}

Most common type of CSOM is tubotympanic type in about 93 ears (78.15\%). Remaining 26 ears (21.85\%) showed atticoantral type of CSOM.

\begin{tabular}{|c|c|c|}
\hline Type & No. of Ears & Percentage \\
\hline Monomicrobial & 61 & 51.26 \\
\hline Polymicrobial & 52 & 43.70 \\
\hline No growth & 6 & 5.04 \\
\hline Total & $\mathbf{1 1 9}$ & $\mathbf{1 0 0}$ \\
\hline \multicolumn{2}{|r|}{ Table 3: Type of Bacterial Culture } \\
\hline
\end{tabular}

Single isolates (Of one genus) were common. Out of 119 ear swabs, 113 swabs grew bacteria and the remaining 6 $(5.04 \%)$ swabs were sterile. Of the 113 swabs that grew bacteria, $61(51.26 \%)$ swabs grew monomicrobial isolates and the remaining $52(43.70 \%)$ swabs grew polymicrobial isolates. 


\begin{tabular}{|c|c|c|}
\hline Nature of Bacteria & No. of Ears & Percentage \\
\hline Only Aerobic & 60 & 50.42 \\
\hline Only Anaerobic & 4 & 3.36 \\
\hline Mixed & 49 & 41.18 \\
\hline No growth & 6 & 5.04 \\
\hline Total & $\mathbf{1 1 9}$ & $\mathbf{1 0 0}$ \\
\hline Table 4: Nature of Bacterial Culture \\
\hline
\end{tabular}

Only aerobic growth is seen in 60 ears (50.42\%), only anaerobic growth is seen in 4 ears (3.36\%), mixed flora are seen in 49 ears (41.18\%) and no growth is seen in 6 ears (5.04\%). Of the only aerobic isolates grown, most of them grew only one genus. The mixed flora obtained contained both aerobic and anaerobic bacteria.

\begin{tabular}{|c|c|c|}
\hline Organism & No. of Isolates & Percentage (\%) \\
\hline $\begin{array}{c}\text { Pseudomonas } \\
\text { Aeruginosa }\end{array}$ & 59 & 50.86 \\
\hline $\begin{array}{l}\text { Staphylococcus } \\
\text { Aureus }\end{array}$ & 33 & 28.45 \\
\hline Proteus spp. & 13 & 11.21 \\
\hline Klebsiella & 4 & 3.45 \\
\hline E. coli & 4 & 3.45 \\
\hline Acinetobacter & 2 & 1.72 \\
\hline Diphtheroids & 1 & 0.86 \\
\hline Total & 116 & 100 \\
\hline
\end{tabular}

were isolated. Out of 168 , most common aerobic bacterium was Pseudomonas aeruginosa (59 out of 168). The next common bacterium observed (Table 5) was Staphylococcus aureus (33 out of 168). The next in order comes Proteus spp. (13 out of 168), Klebsiella spp. (4 out of 168) and Acinetobacter (2 out of 168) and diphtheroids (1 out of 168). of the aerobic combinations obtained in some ears, the common combination was pseudomonas and staphylococcus.

\begin{tabular}{|c|c|c|}
\hline Organism & No. of Isolates & Percentage (\%) \\
\hline Peptostreptococcus & 21 & 40.38 \\
\hline Prevotella & 13 & 25.00 \\
\hline Porphyromonas & 10 & 19.23 \\
\hline Bacteroides & 6 & 11.54 \\
\hline Peptococcus & 2 & 3.85 \\
\hline Total & 52 & 100 \\
\hline \multicolumn{3}{|c|}{ Table 6: Anaerobic Organisms Isolated } \\
\hline
\end{tabular}

Out of 168 (both aerobic and anaerobic) bacterial isolates, the most common anaerobic bacterium was Peptostreptococcus (21 out of 168). The next common bacterium observed was Prevotella (Table 6) (13 out of 168). The next in order comes porphyromonas (10 out of 168$)$, Bacteroides (6 out of 168) and Peptococcus (2 out of 168).

A total no. of 168 (Both aerobic and anaerobic) bacteria

\begin{tabular}{|c|c|c|c|c|c|c|c|c|}
\hline Organism & Ampicillin & Amoxicillin & Ciprofloxacin & Cotrimoxazole & Ceftazidime & Cefotaxime & Ceftriaxone & Ofloxacin \\
\hline $\begin{array}{l}\text { Pseudomonas } \\
\text { Sensitive }\end{array}$ & $\begin{array}{c}17 \\
(28.81 \%) \\
\end{array}$ & $\begin{array}{c}18 \\
(30.50 \%) \\
\end{array}$ & $\begin{array}{c}22 \\
(37.28 \%) \\
\end{array}$ & $\begin{array}{c}23 \\
(38.98 \%) \\
\end{array}$ & $\begin{array}{c}45 \\
(76.27 \%) \\
\end{array}$ & $\begin{array}{c}47 \\
(79.66 \%) \\
\end{array}$ & $\begin{array}{c}37 \\
(62.71 \%) \\
\end{array}$ & $\begin{array}{c}26 \\
(44.07 \%) \\
\end{array}$ \\
\hline $\begin{array}{c}\text { Pseudomonas } \\
\text { Resistant }\end{array}$ & $\begin{array}{c}42 \\
(71.19 \%)\end{array}$ & $\begin{array}{c}41 \\
(69.50 \%)\end{array}$ & $\begin{array}{c}37 \\
(62.72 \%)\end{array}$ & $\begin{array}{c}36 \\
(61.02 \%)\end{array}$ & $\begin{array}{c}14 \\
(23.73 \%)\end{array}$ & $\begin{array}{c}12 \\
(20.34 \%)\end{array}$ & $\begin{array}{c}22 \\
(37.29 \%)\end{array}$ & $\begin{array}{c}33 \\
(55.93 \%)\end{array}$ \\
\hline $\begin{array}{l}\text { Staphylococcus } \\
\text { Sensitive }\end{array}$ & $\begin{array}{c}8 \\
(24.24 \%)\end{array}$ & $\begin{array}{c}8 \\
(24.24 \%)\end{array}$ & $\begin{array}{c}11 \\
(33.33 \%)\end{array}$ & $\begin{array}{c}12 \\
(36.36 \%)\end{array}$ & $\begin{array}{c}25 \\
(75.76 \%)\end{array}$ & $\begin{array}{c}27 \\
(81.81 \%)\end{array}$ & $\begin{array}{c}18 \\
(54.54 \%)\end{array}$ & $\begin{array}{c}15 \\
(45.46 \%)\end{array}$ \\
\hline $\begin{array}{l}\text { Staphylococcus } \\
\text { Resistant }\end{array}$ & $\begin{array}{c}25 \\
(75.76 \%)\end{array}$ & $\begin{array}{c}25 \\
(75.76 \%)\end{array}$ & $\begin{array}{c}22 \\
(66.67 \%)\end{array}$ & $\begin{array}{c}21 \\
(63.64 \%)\end{array}$ & $\begin{array}{c}8 \\
(24.24 \%)\end{array}$ & $\begin{array}{c}6 \\
(18.19 \%)\end{array}$ & $\begin{array}{c}15 \\
(45.46 \%)\end{array}$ & $\begin{array}{c}18 \\
(54.54 \%)\end{array}$ \\
\hline $\begin{array}{l}\text { Proteus } \\
\text { Sensitive }\end{array}$ & $\begin{array}{c}5 \\
(38.46 \%)\end{array}$ & $\begin{array}{c}6 \\
(46.15 \%)\end{array}$ & $\begin{array}{c}4 \\
(30.76 \%)\end{array}$ & $\begin{array}{c}4 \\
(30.76 \%)\end{array}$ & $\begin{array}{c}10 \\
(76.92 \%)\end{array}$ & $\begin{array}{c}12 \\
(92.30 \%)\end{array}$ & $\begin{array}{c}10 \\
(76.92 \%)\end{array}$ & $\begin{array}{c}6 \\
(46.15 \%)\end{array}$ \\
\hline $\begin{array}{c}\text { Proteus } \\
\text { Resistant }\end{array}$ & $\begin{array}{c}8 \\
(61.54 \%)\end{array}$ & $\begin{array}{c}7 \\
(53.85 \%) \\
\end{array}$ & $\begin{array}{c}9 \\
(69.24 \%)\end{array}$ & $\begin{array}{c}9 \\
(69.24 \%)\end{array}$ & $\begin{array}{c}3 \\
(23.08 \%)\end{array}$ & $\begin{array}{c}1 \\
(7.70 \%)\end{array}$ & $\begin{array}{c}3 \\
(23.08 \%)\end{array}$ & $\begin{array}{c}7 \\
(53.85 \%)\end{array}$ \\
\hline $\begin{array}{l}\text { Klebsiella } \\
\text { Sensitive }\end{array}$ & $\begin{array}{c}1 \\
(25 \%)\end{array}$ & $\begin{array}{c}1 \\
(25 \%)\end{array}$ & $\begin{array}{c}4 \\
(100 \%)\end{array}$ & $\begin{array}{c}2 \\
(50 \%)\end{array}$ & $\begin{array}{c}4 \\
(100 \%)\end{array}$ & $\begin{array}{c}4 \\
(100 \%)\end{array}$ & $\begin{array}{c}4 \\
(100 \%) \\
\end{array}$ & $\begin{array}{c}4 \\
(100 \%) \\
\end{array}$ \\
\hline $\begin{array}{l}\text { Klebsiella } \\
\text { Resistant }\end{array}$ & $\begin{array}{c}3 \\
(75 \%)\end{array}$ & $\begin{array}{c}3 \\
(75 \%)\end{array}$ & $\begin{array}{c}0 \\
(0 \%)\end{array}$ & $\begin{array}{c}2 \\
(50 \%)\end{array}$ & $\begin{array}{c}0 \\
(0 \%)\end{array}$ & $\begin{array}{c}0 \\
(0 \%)\end{array}$ & $\begin{array}{c}0 \\
(0 \%)\end{array}$ & $\begin{array}{c}0 \\
(0 \%)\end{array}$ \\
\hline $\begin{array}{c}\text { E. coli } \\
\text { Sensitive }\end{array}$ & $\begin{array}{c}2 \\
(50 \%)\end{array}$ & $\begin{array}{c}4 \\
(100 \%)\end{array}$ & $\begin{array}{c}2 \\
(50 \%)\end{array}$ & $\begin{array}{c}2 \\
(50 \%)\end{array}$ & $\begin{array}{c}1 \\
(25 \%)\end{array}$ & $\begin{array}{c}1 \\
(25 \%)\end{array}$ & $\begin{array}{c}1 \\
(25 \%)\end{array}$ & $\begin{array}{c}3 \\
(75 \%)\end{array}$ \\
\hline $\begin{array}{c}\text { E. coli } \\
\text { Resistant }\end{array}$ & $\begin{array}{c}2 \\
(50 \%)\end{array}$ & $\begin{array}{c}0 \\
(0 \%)\end{array}$ & $\begin{array}{c}2 \\
(50 \%)\end{array}$ & $\begin{array}{c}2 \\
(50 \%)\end{array}$ & $\begin{array}{c}3 \\
(75 \%)\end{array}$ & $\begin{array}{c}3 \\
(75 \%)\end{array}$ & $\begin{array}{c}3 \\
(75 \%)\end{array}$ & $\begin{array}{c}1 \\
(25 \%)\end{array}$ \\
\hline $\begin{array}{l}\text { Acinetobacter } \\
\text { Sensitive }\end{array}$ & $\begin{array}{c}0 \\
(0 \%)\end{array}$ & $\begin{array}{c}0 \\
(0 \%)\end{array}$ & $\begin{array}{c}0 \\
(0 \%)\end{array}$ & $\begin{array}{c}2 \\
(100 \%)\end{array}$ & $\begin{array}{c}0 \\
(0 \%)\end{array}$ & $\begin{array}{c}0 \\
(0 \%)\end{array}$ & $\begin{array}{c}2 \\
(100 \%)\end{array}$ & $\begin{array}{c}0 \\
(0 \%)\end{array}$ \\
\hline $\begin{array}{c}\text { Acinetobacter } \\
\text { Resistant }\end{array}$ & $\begin{array}{c}2 \\
(100 \%)\end{array}$ & $\begin{array}{c}2 \\
(100 \%)\end{array}$ & $\begin{array}{c}2 \\
(100 \%) \\
\end{array}$ & $\begin{array}{c}0 \\
(0 \%)\end{array}$ & $\begin{array}{c}2 \\
(100 \%)\end{array}$ & $\begin{array}{c}2 \\
(100 \%)\end{array}$ & $\begin{array}{c}0 \\
(0 \%) \\
\end{array}$ & $\begin{array}{c}2 \\
(100 \%) \\
\end{array}$ \\
\hline $\begin{array}{l}\text { Diphtheroids } \\
\text { Sensitive }\end{array}$ & $\begin{array}{c}1 \\
(100 \%)\end{array}$ & $\begin{array}{c}1 \\
(100 \%)\end{array}$ & $\begin{array}{c}1 \\
(100 \%)\end{array}$ & $\begin{array}{c}1 \\
(100 \%)\end{array}$ & $\begin{array}{c}1 \\
(100 \%)\end{array}$ & $\begin{array}{c}1 \\
(100 \%)\end{array}$ & $\begin{array}{c}1 \\
(100 \%) \\
\end{array}$ & $\begin{array}{c}1 \\
(100 \%) \\
\end{array}$ \\
\hline $\begin{array}{l}\text { Diphtheroids } \\
\text { Resistant }\end{array}$ & $\begin{array}{c}0 \\
(0 \%) \\
\end{array}$ & $\begin{array}{c}0 \\
(0 \%) \\
\end{array}$ & $\begin{array}{c}0 \\
(0 \%) \\
\end{array}$ & $\begin{array}{c}0 \\
(0 \%) \\
\end{array}$ & $\begin{array}{c}0 \\
(0 \%) \\
\end{array}$ & $\begin{array}{c}0 \\
(0 \%) \\
\end{array}$ & $\begin{array}{c}0 \\
(0 \%) \\
\end{array}$ & $\begin{array}{c}0 \\
(0 \%) \\
\end{array}$ \\
\hline
\end{tabular}

\section{DISCUSSION}

Chronic suppurative otitis media and its complications are seen by the otologist, paediatrician and the general practitioner. It is a recurring disease with great risk of lifethreatening complications. Early bacteriological diagnosis of all cases will provide accurate therapy.

The incidence of chronic suppurative otitis media is subject to large regional variations and its frequency is low in areas with a trained medical group, good hygiene, facility of the population for access to medical treatment. In regions 
where overcrowding with poor environmental hygiene precipitates chronic ear disease.

In this study, patients who presented to our OPD were taken. Patients who have used prior antibiotics for 3 days were excluded.

Majority of patients in the present study had symptoms for less than 10 years. But out of 100 patients (119 ears), 10 ears had discharge for more than 10 years. These results were in accordance with Jose Evandro Andrade. In the study by Kenna et al. (1986), duration of symptoms ranging from less than 3 months to 3 years and more. Rupa et al. 1999 observed a long duration greater than 10 years and said that it may be due to the reason that Indian patients are reluctant to seek medical advice because of their ignorance.

In my study, majority had tubotympanic disease (78.15\%) as compared to atticoantral disease $(21.85 \%)$. This is consistent with the results obtained by VK Poorey et al. ${ }^{8}$ (TT 72\%, AA 28\%).

Out of 100 cases (119 ears) studied, monomicrobial growth was obtained from $61(51.26 \%)$ ears, polymicrobial growth was seen in $52(43.70 \%)$ ears and no growth in 6 (5.04\%) ears.

These findings with regard to monomicrobial predominance were in accordance with AHC Loy et al. (63.3\%), Srivastava A.9 , A Haider A. ${ }^{10}$ (80.7\%) and VK Poorey et al. ${ }^{8}(82 \%)$. A combination of the different aerobes and anaerobes varied and there was no consistent pattern of combinations.

In this study, Pseudomonas aeruginosa was the most common organism (50.86\%) followed by Staphylococcus aureus (28.45\%), Proteus spp. (11.21\%), Klebsiella (3.45\%), Escherichia coli (3.45\%), Acinetobacter (1.72\%) and Diphtheroids (0.86\%).

This study agrees with the reports of Tahira.11 VK Poorey. ${ }^{8}$ and Gul.12 who also got Pseudomonas as the common organism. Ahmed. ${ }^{13}$ and Srivastava. ${ }^{9}$ showed Staphylococcus as the common organism, whereas Loy had got an equal number of Pseudomonas and Staphylococcus.

Only 4 ears showed pure anaerobic culture (3.36\%), out of which 3 were peptostreptococci and one was Peptococcus. Most of the anaerobic organisms isolated were in combination with aerobes $(96.64 \%)$. The most common was Peptostreptococcus (40.38\%) followed by Prevotella (25\%), Porphyromonas (19.23\%), Bacteroides (11.54\%) and Peptococcus $(3.85 \%)$. These results were similar to Jonsson et al. who observed that Peptostreptococci (55\%) were common as compared to Bacteroides (33\%).

Saini et al. ${ }^{14}$ showed that Peptostreptococcus was commonest in paediatric CSOM and Prevotella was commonest in adult CSOM. Bacteroides (44\%) was predominant according to Sweeny et al. Anaerobes have been isolated in a few studies; $61 \%$ of patients in the study by Erken et al. (1994) showed anaerobes. Brook et al.15 (1987) report $86 \%$ patients had anaerobic infection. Improved bacteriological methods may be said to be the reason for this high yield. Anaerobes are not a significant pathogen in their study according to Srivastava. ${ }^{9}$ and Loy.

In the present study, it was noted that Pseudomonas was the commonest organism in both tubotympanic (50\%) and atticoantral disease (53.84\%). The next most common was Staphylococcus aureus in both tubotympanic (30\%) and atticoantral (23.08\%). Jose Evandro Andrade. 16 showed that
Staphylococcus aureus was the commonest in both tubotympanic (21\%) and atticoantral (15\%) and the next commonest was Pseudomonas, tubotympanic (15\%) and atticoantral (7\%) respectively. Attalah observed that Staphylococcus was common in ears with cholesteatoma. Among anaerobes, Peptostreptococcus is common in both Tubotympanic disease (32.43\%) and atticoantral disease $(60 \%)$. There was no significant data in the literature describing the commonest anaerobic organisms in both types of CSOM.

In this study, Pseudomonas showed maximum sensitivity (79.66\%) to cefotaxime. Next sensitive drugs were ceftazidime $(76.27 \%)$, ceftriaxone $(62.71 \%)$ and Ofloxacin (44.07\%), cotrimoxazole (38.98), ciprofloxacin (37.28\%). Ampicillin (28.81\%) and amoxicillin (30.50\%) showed least sensitivity. Gul (84.1\%), Tahira.11 (89\%) and Pajor (98\%) showed maximum sensitivity to ceftazidime for Pseudomonas, while Nikakhlagh. ${ }^{17}$ obtained $81.2 \%$ resistance to ceftazidime. Maji et al. ${ }^{18}$ Haider. $^{10}$ Saini. ${ }^{14}$ obtained maximum sensitivity to cefotaxime, whereas Pajor and Nikakhlagh. ${ }^{17}$ showed resistance as $33.3 \%$ and $100 \%$ resistance respectively to cefotaxime.

The sensitivity of Pseudomonas to fluoroquinolones had shown a downward trend globally in recent past. Gul.12 and Tahira. ${ }^{11}$ showed ciprofloxacin sensitivity as $95 \%$ and $85 \%$ respectively, whereas in South Korea in a study carried out by Jang, ciprofloxacin resistance was noted in $100 \%$ of the isolates. Maji et al. ${ }^{18}$ showed $46.6 \%$ sensitivity to ciprofloxacin. Kumar et al. reported $63.2 \%$ sensitivity to ofloxacin and $59.6 \%$ sensitivity for ciprofloxacin.

This decreased sensitivity of Pseudomonas to quinolone family to which it was highly sensitive until recently, is indicative of the rapid appearance of antibiotic resistant strains which is a matter of great concern. Ahmed et al.13 showed least resistance to ampicillin and cotrimoxazole. The observations with regards to amoxicillin and ampicillin in my study were similar to the data obtained by Indudharan et al. ${ }^{19}$ Srivastava et al. ${ }^{9}$ and Ettehad et al. ${ }^{20}$

In my study the sensitivity of Staphylococcus to ampicillin, amoxicillin, ciprofloxacin, cotrimoxazole, ceftazidime, cefotaxime, ceftriaxone and ofloxacin were $24.24 \%, 24.24 \%, 33.33 \%, 33.36 \%, 75.76 \%, 81.81 \%$, 54.54\% and $45.46 \%$ respectively. Similar results with regard to cephalosporins were obtained by Nikakhlagh. ${ }^{17}$ who had stated $100 \%$ and $87.5 \%$ sensitivity to ceftazidime and cefotaxime respectively. VK Poorey. ${ }^{8}$ Haider. ${ }^{10}$ Maji et al. ${ }^{18}$ showed more sensitivity to cefotaxime, which is consistent with the present study. VK Poorey. ${ }^{8}$ (93\%) showed that ciprofloxacin was sensitive to Staphylococcus. Irfan and Ahmed. ${ }^{19}$ showed less sensitivity to cotrimoxazole, i.e. $32 \%$ and $2.5 \%$ respectively. Sensitivity to ampicillin and amoxicillin to Staphylococcus is significantly less in studies carried out by Ahmed. ${ }^{19}$ and Maji et al. ${ }^{18}$ Proteus and Klebsiella showed maximum sensitivity to third generation cephalosporins especially cefotaxime, ceftazidime and ceftriaxone and ofloxacin which is consistent with the results obtained by Srivastava et al. ${ }^{9}$ and VK Poorey. ${ }^{8}$ They exhibited highest resistance to ampicillin and cotrimoxazole, which is consistent with the observations of Ahmed. ${ }^{19}$

Other isolates (i.e. proteus, klebsiella and diphtheroids which were not significant pathogens in this study showed more sensitivity to third generation cephalosporins and 
fluoroquinolones, viz. cefotaxime, ceftazidime, ceftriaxone, ciprofloxacin and ofloxacin while displaying high resistance to other drugs used, whereas E. coli has shown maximum sensitivity to Amoxicillin and Acinetobacter has shown maximum sensitivity to ceftriaxone and cotrimoxazole.

The prescription of antibiotics by physicians and practitioners lack specific treatment resulting in microbial resistance. So, it is very much needed that the doctors should have knowledge about the changing pattern of causative agents against drugs and should not prescribe such antibiotics and in addition to that patients also should be educated to avoid misuse of antibiotics.

\section{CONCLUSION}

In this study, bacteria from the ear discharge in chronic suppurative otitis media were grown from the middle ear discharge. The present study showed the wide range of aerobic and anaerobic organisms, which include Pseudomonas followed by Staphylococcus and Peptostreptococci followed by Prevotella: Both Pseudomonas and Staphylococcus and all other aerobic isolates were most sensitive to cefotaxime, ceftazidime and ceftriaxone. They showed high resistance to penicillins and cotrimoxazole. This might have been due to their widespread and injudicious useThus careful selection and judicious use of antibiotic with antibiotics sensitivity test help to reduce autological cure and morbidity.

\section{REFERENCES}

1. Bluestone CD, Gates GA, Klein JO, et al. Definitions, terminology and classification of otitis media. Annals of Otology, Rhinology and Laryngology 2002;111:8-18.

2. WHO/CIBA foundation work shop. Prevention of hearing impairment from chronic otitis media London 1996. Geneva: World health organization 1998;19-21.

3. Healy GB, Rosbe KW. Otitis media and middle ear effusions in snow. Ballenger JJ, Editors. Ballengers otolaryngology head neck surgery. BC Decker inc, 2003; 16th ed:249-60.

4. Finegold SM, Wexler HM. The rapeutic implications of bacteriologic findings in mixed aerobic and anaerobic infections. Antimicrob agents chemother 1988;32(5):61116.

5. Couzos S, Lea T, Mullar R, et al. Effectiveness of ototopical antibiotics for CSOM in aboriginal children, a community based multi center double blind randomized controlled trial. Med J Aust 2003;179(4):185-90.

6. Alan E Dugdale. Management of chronic suppurative otitis media. Med J Aust 2004;180(2):91-93.

7. Fairbanks DN. Antimicrobial therapy for CSOM. Ann Otol Rhinol Laryngol 1981;90(3 Pt 3):58-62.
8. Poorey VK, Arati Iyer. Study of bacterial flora in CSOM and its clinical significance. Indian Journal of Otolaryngology and Head and Neck Surgery 2002;54(2):91-95.

9. Srivastava A, Singh RK, Varshny S, et al. Microbiological evaluation of an active tubotympanic type of chronic suppurative otits media. Nepalese Journal of ENT Head \& Neck Surgery 2010;1(2):14-16.

10. Haider A. Chronic suppurative otitis media (CSOM): bacteriological study. The Orion Medical Journal 2002;13:13-14.

11. Tahira Mansoor, Mohammed Ayub Musani, Gulnaz Khalid, et al. Pseudomonas aeruginosa in chronic suppurative otitis media: sensitivity spectrum against various antibiotics in Karachi. J Ayub Med Coll Abbottabad 2009;21(2):120-3.

12. Asif Alam gul, Liaqat ali, Ejaz Rahim, et al. Chronic suppurative otitis media: frequency of pseudomonas aeruginosa in patients and its sensitivity to various antibiotics. Professional medical J 2007;14(3):411-415.

13. Ahmad BM, Kudi MT. Chronic suppurative otitis media in gombe, Nigeria. The Nigerian Journal of Surgical Research 2003;5(3):120-123.

14. Saini S, Gupta N, Aparna, et al. Bacteriological study of paediatric and adult chronic suppurative otitis media. Indian J Pathol Microbiol 2005;48(3):413-6.

15. Brook I. Prevalence of beta-lactamase producing bacteria in chronic suppurative otitis media. Am J child 1985;139(3):280-283.

16. Jose Evandro Andrade Prudente de Aquino, Salomão H Pererira, Julia Negro Prudente de Aquino. Bacterial findings found in the chronic otitis media secretion: comparitive study between cholesteatoma (OMCC) and simple otitis media (SCOM). International Archieves 2009;13(3).

17. Nikakhlagh S, Khosravi AD, Fazlipour AM, et al. Microbiologic findings in patients with chronic suppurative otitis media. Journal of Medical Sciences 2008;8:503-506.

18. Maji PK, Chatterjee TK, Chatterjee $S$, et al. The investigation of bacteriology of chronic suppurative otitis media in patients attending a tertiary care hospital with special emphasis on seasonal variation. Indian J Otolaryn Head Nack Surg 2007;59(2):128-31.

19. Indudharan R, Haq JA, Aiyar S. Antibiotics in chronic suppurative otitis media-a bacteriologic study. Ann Otol Rhinol Laryngol 1999;108(5):440-445.

20. Ettehad G, Refani S, Nemmati A, et al. Microbial and antimicrobial susceptibility patterns from patients with COM in Ardebil. Int J Tropi Med 2006;1(2):6-5. 